\title{
Readiness of Forest Officers for Adaptations in Forest Management Planning
}

\author{
Christoph HARTEBRODT ${ }^{*}$ - Julia SCHMITT \\ Department of Forest Economics, Forest Research Institute Baden-Württemberg, Freiburg, Germany
}

\begin{abstract}
Under the framework of a society that enhances the demand for different kinds of ecosystem services, "Forest Management Planning" (FMP) has changed notably over the last decades. As a consequence of budget constraints and the fact that the present forest planning system of the State Forest Administration of Baden-Württemberg has been in operation since 2000, this system has to be developed further. Since the group of forest officers at the county level is the largest user group, it was decided to start a participatory process in order to derive the most relevant requirements of that group. A survey within the board of managing directors followed. In order to gain an insight into the requirements and preferences we used the pairwise comparison method. The paper highlights the preference structure in respect to (1) the goals of FMP, (2) target groups, (3) the FMP process, (4) tasks, (5) and the outputs of FMP. It can be shown that the average percipience of FMP of forest officers tends to be more traditional and internal than proactive and stakeholder-oriented. The pairwise comparison approach has been proven successful as a means to get insight in the preference structures.
\end{abstract}

integrated planning / internal participation / readiness for change / plurality of opinions

Kivonat - Az erdészeti szakszemélyzet alkalmazkodási készsége az erd tervezés folyamatában. Azon társadalmi keretek között, amelyek a különböz ökoszisztéma szolgáltatások keresletét er sítették, az erd tervezés észrevehet en megváltozott az utóbbi évtizedekben. A költségvetési korlátok, valamint az a tény, hogy a Baden-Württemberg tartomány jelenlegi állami erd tervezési rendszere 2000 óta van érvényben, szükségessé teszik a továbbfejlesztését. Mivel az erd tervek legf bb felhasználója az erdészeti szakszemélyzet, ezért a részvételükre alapozott folyamat indult el a legfontosabb elvárásaik feltárására. Ezt egy döntéshozói felmérés követte. Annak érdekében, hogy az elvárások és preferenciák körér 1 bels információk álljanak rendelkezésre, a páronkénti összehasonlítás módszerét alkalmazták. A cikk rávilágít a preferenciák rendszerére (1) az erd tervezés céljai (2) a célcsoportok, (3) az erd tervezési folyamat, (4) a feladatok, (5) az erd tervezés kimenetei tekintetében. Kimutatható, hogy az erdészeti szakszemélyzet erd tervezéssel kapcsolatos átlagosnak mondható szemlélete jellemz en tradicionális és befelé forduló, és kevésbé proaktív és érdekeltirányultságú. A páronkénti összehasonlítás sikeres módszernek bizonyult a preferencia szerkezet feltárására.

integrált tervezés / részvételi folyamat / változtatási hajlandóság / vélemények sokszín sége

\footnotetext{
* Corresponding author: christoph.hartebrodt@ forst.bwl.de; Wonnhaldestraße 4, D-79100 FREIBURG
} 


\section{INTRODUCTION}

The role of Forest Management Planning (FMP) has changed notably over the last decades. Until the late seventies FMP was mostly seen as an internal, mostly technical procedure, primarily focusing on the productive function of forests. Especially under the framework conditions of a densely populated county with, on average, a highly educated population, the role of forests has changed more and more towards a supplier of various ecosystem services. Except for all kinds of timber processing industries and an initially small, but increasing, number of private timber consumers, the societal interests are concentrated mainly in the recreational and environmental functions of forests. Together with this shift in interests the demand for participatory processes has grown larger. Whenever the use of instruments that are related to sustainable development is foreseen, participation is a standard step during the development, implementation, and mostly during the use of the respective instrument (e. g. sustainability reporting (GRI 2103) and the Agenda 21 processes (Heinrichs 2007, Feindt - Newig 2005). There are substantial findings which suggest that planning procedures are seen as good opportunities for communication with and participation of various kinds of stakeholder groups (Sheppard 2005, Joint FAO/ECE/ILO Committee 2000, cited in Beck 2011).

It is not only the external participation, however, that contributes to the success of FMP systems. As these systems are used by a potentially maximum share of members in almost every forest institution, the acceptance of the FPM and other instruments in place can be seen as a key success factor for their application. A means to achieve a sufficient level of acceptance is the involvement of users in the development process (Hartebrodt 2009). Consecutively, not only external participation has to be considered, but also internal participatory processes have to become part of the revision of existing instruments.

The change of societal requirements resulted, at least in Germany, in an increasing dispute between forest owners and/or administrations and stakeholder groups. In particular, environmentalists tend to be generally sceptical and mistrusting towards timber harvesting or at least towards a higher share of conventional management practices. Owners and forest practitioners highlight the increasing demand for all kinds of wood-based raw materials and underline the important role of forest utilisation in a bio-based economy. The willingness to adopt new requirements in the management practice differs widely despite the fact that a relevant part of these requirements rests on the present legal framework, for instances the European Framework Directive on 'Flora, Fauna, Habitat' (European Commission 1992). This directive leads (among other things) indirectly to the upcoming idea of implementing the so-called integrated management plans, which cover both the management of forest production and the management of ecological issues (European Commission 2013).

\section{AIM OF THE STUDY}

The purpose of the study was two-fold. First, the objective was to develop a deep and detailed insight into the preferences and requirements of different internal user groups of FMP. The pattern of the preferences was foreseen to be used as a set of decisive criteria for the ongoing revision process of the FMP system. Of special interest was the question whether forest practitioners are ready for an integration of external requirements in FMP and the involvement of stakeholder groups in the FMP process.

Second, it was of interest, if, and to what extent, elements of a decision support system and the related participatory processes are suited in the context of such kind of revision process. Furthermore, it was planned to analyse the consistency of the results in various substrata, the ability of the process to provide additional information about the hetero- or homogeneity of the opinions and the acceptance of the decision process. 


\section{CASE STUDY}

We used the revision process of the FMP-system of the State Forest Administration of BadenWürttemberg (SFA-BW) as a case study. SFA-BW is organised as a so-called joint forest administration responsible for all types of forest owners (state-owned, communal and private). The state forest service manages the state forest, is responsible for assistance and (technical) support of other forest owners, as well as for the distribution of financial allowances. The state forest administration is essentially responsible for the "planning, preparation, organisation, management and supervision of all kinds of forest management activities" (LWaldG 2012: §47 (1) [translation by the author]) in communal forests. Communal authorities can decide whether to take over this responsibility or not; however, as the state service is free of charge, most communal bodies do not choose to do so. Part of this 'service-package' is the process of the FMP, which takes place every 10 years. The FMP is carried out by one department of the middle administrational level. As most communal bodies make use of the state service, there is, consequently, generally one FMP process in place. The revision of this process is used as a case-model for the present study.

Before a final decision about the general structure of the revised FMP process could be made, the board of managers decided first that the needs and requirements of the main user group, which is the forest staff at the county level, should be studied in a way that is able to produce reliable, trustworthy, and presentable results. The main areas of interests (later on dimensions) were objectives (1) and tasks (2) of FMP, as well as tools and products (3) provided by FMP. The CEO defined the need that a clear prioritisation should be undertaken in respect to all dimensions. During the process the decision was made to identify the most important user groups (4) and relevant process steps (5) of FMP as well. During the workshops, information needs were additionally gathered. These results are not included in this paper. It has to be mentioned that there are two FMP-traditions (the western and eastern part of Baden-Württemberg). After a mid-term presentation of the results gathered from amongst representatives of the county level, it was decided to involve the departments of topand middle-level management and those of the state forest research institute.

\section{METHODS AND DATA}

\section{Methods}

\section{Workshop with Representatives of the County Level}

The results concerning the opinion of the members of the county level were collected during two workshops (WS 1 and WS 2) in December, 2013. In order to determine whether there is a notable difference within the state of Baden-Württemberg, one WS was carried out in the western and one in the eastern part of the state. One had, however, also the option of attending either WS. The WS-procedure in dimensions (which are discussed later in the paper) was as follows: Based on a proposed list of items in each dimension the participants developed a final list and discussed it in terms of their present use and its frequency at the county level. This in-depth discussion was documented on posters and remained visible during the final evaluation session as background information for the participants.

For the final evaluation of the priority of each item we used the pairwise comparison approach (comp. Saaty 2008), which is regarded as suitable for prioritisation of intangible factors. Based on an Excel solution it was possible to transfer the lists of items into a (hard copy) questionnaire, which was filled out by the participants at the final evaluation session. Figure la depicts a completed questionnaire in the dimension 'objectives' (Ziele). 
Figure 1a

Ziele

\begin{tabular}{|c|c|c|c|c|}
\hline & + & $=$ & + & \\
\hline \begin{tabular}{|l} 
Gesetzi. Auftrag \\
Nachhaltigkeitssicherung
\end{tabular} & & & & Zentrale Datenhaltung offentl. Wald \\
\hline \begin{tabular}{|l|} 
Betriebssteuerung \\
Betriebsleitung Land \\
\end{tabular} & & & & Zentrale Datenhaltung offentl. Wald \\
\hline \begin{tabular}{|l|} 
Betriebssteuerung \\
Betriebsteile UFB
\end{tabular} & & & & Zentrale Datenhaltung offentl. Wald \\
\hline \begin{tabular}{|l|} 
Gesetzl. Auftrag \\
Nachhaltigkeitssicherung
\end{tabular} & & & & Kundenzufriedenheit \\
\hline \begin{tabular}{|l} 
Betriebssteuerung \\
Betriebsleitung Land
\end{tabular} & & & & Kundenzufriedenheit \\
\hline \begin{tabular}{|l} 
Betriebssteuerung \\
Betriebsteile UFB
\end{tabular} & & & & Kundenzufriedenheit \\
\hline $\begin{array}{l}\text { Zentrale Datenhaltung offentl. } \\
\text { Wald }\end{array}$ & & & & Kundenzufriedenheit \\
\hline Einheitliche Datenstruktur & & & & Kundenzufriedenheit \\
\hline \begin{tabular}{|l|} 
Gesetzl. Auftrag \\
Nachhaltigkeitssicherung
\end{tabular} & & & & Klârung Eigentömer Zielsetzung \\
\hline \begin{tabular}{|l|} 
Betriebssteuerung \\
Betriebsleitung Land
\end{tabular} & & & & Klărung Eigentamer Zielsetzung \\
\hline \begin{tabular}{|l} 
Betriebssteuerung \\
Betriebsteile UFB
\end{tabular} & & & & Klărung Eigentumer Zielsetzung \\
\hline $\begin{array}{l}\text { Zentrale Datenhaltung offent. } \\
\text { Wald }\end{array}$ & & & & Klärung Eigentümer Zielsetzung \\
\hline Einheitliche Datenstruktur & & & & Klărung Eigentümer Zielsetzung \\
\hline Kundenzufriedenheit & & & & Klarung Eigentumer Zielsetzung \\
\hline \begin{tabular}{|l|} 
Fortbildung \\
\end{tabular} & & & $\sum$ & Klärung Eigentumer Zielsetzung \\
\hline $\begin{array}{l}\text { Gesetzl. Auftrag } \\
\text { Nachhaltiokeitssicherung }\end{array}$ & & & & Fortbildung \\
\hline $\begin{array}{l}\text { Betriebssteuerung } \\
\text { Betriebsleitung Land }\end{array}$ & & & & Fortbildung \\
\hline \begin{tabular}{|l|} 
Betriebssteuerung \\
Betriebsteile UFB
\end{tabular} & & & & Fortbildung \\
\hline $\begin{array}{l}\text { Zentrale Datenhaltung offentl. } \\
\text { Wald }\end{array}$ & & & & Fortbildung \\
\hline Einheitliche Datenstruktur & & & & Fortbildung \\
\hline Kundenzufriedenheit & & & & Fortbildung \\
\hline $\begin{array}{l}\text { Gesetzl. Auftrag } \\
\text { Nachhaltigkeitssicherung }\end{array}$ & & & & Einheitliche Datenstruktur \\
\hline \begin{tabular}{|l|} 
Betriebssteuerung \\
Betriebsleitung Land
\end{tabular} & & & & Einheitliche Datenstruktur \\
\hline $\begin{array}{l}\text { Betriebssteuerung } \\
\text { Betriebsteile UFB }\end{array}$ & & & & Einheitliche Datenstruktur \\
\hline $\begin{array}{l}\text { Zentrale Datenhaltung offentl. } \\
\text { Wald }\end{array}$ & & & & Einheitliche Datenstruktur \\
\hline $\begin{array}{l}\text { Gesetzl. Auftrag } \\
\text { Nachhaltigkeitssicherung }\end{array}$ & & & & $\begin{array}{l}\text { Betriebssteuerung Betriebsteile } \\
\text { UFB }\end{array}$ \\
\hline $\begin{array}{l}\text { Betriebssteuerung } \\
\text { Betriebsleitung Land }\end{array}$ & & & & $\begin{array}{l}\text { Betriebssteuerung Betriebsteile } \\
\text { UFB }\end{array}$ \\
\hline $\begin{array}{l}\text { Gesetzl. Auftrag } \\
\text { Nachhaltigkeitssicherung }\end{array}$ & & & & $\begin{array}{l}\text { Betriebssteuerung Betriebsleitung } \\
\text { Land }\end{array}$ \\
\hline
\end{tabular}

Figure $1 b$

\begin{tabular}{|c|c|c|c|c|c|c|c|c|c|c|}
\hline \begin{tabular}{|l}
$0=$ weniger \\
wichtig(Zeilenkriterium < \\
Spaltenkriterium) \\
1= gleichgewichtig \\
(Zeilenkriterium = \\
Spaltenkriterium) \\
2= wichtiger \\
(Zeilenkriterium > \\
Spaltenkriterium)
\end{tabular} & 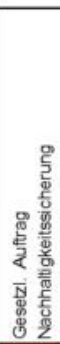 & 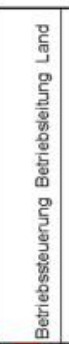 & 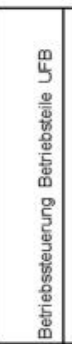 & 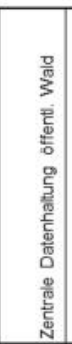 & 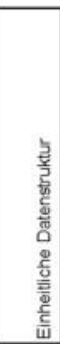 & 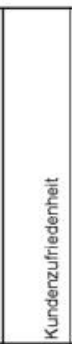 & 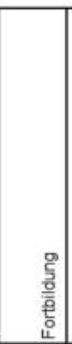 & 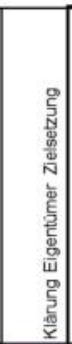 & 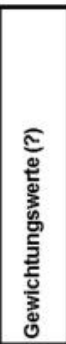 & 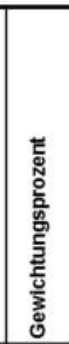 \\
\hline $\begin{array}{l}\text { Gesetzl. Auftrag } \\
\text { Nachhaltigkeitssich }\end{array}$ & & & 2 & 2 & 2 & 2 & 2 & 1 & 13 & 23 \\
\hline $\begin{array}{l}\text { Betriebssteuerung } \\
\text { Betriebsleitung Land }\end{array}$ & & & 1 & 1 & 1 & & 1 & 0 & 4 & 7 \\
\hline $\begin{array}{l}\text { Betriebssteuerung } \\
\text { Betriebsteile UFB }\end{array}$ & 0 & 1 & & 2 & 2 & 1 & 1 & 1 & 8 & 14 \\
\hline $\begin{array}{l}\text { Zentrale Datenhaltung öffentl. } \\
\text { Wald }\end{array}$ & 0 & 1 & 0 & & 1 & 0 & 0 & 0 & 2 & 4 \\
\hline Einheitliche Datenstruktur & 0 & 1 & 0 & 1 & & 0 & 1 & 0 & 3 & 5 \\
\hline Kundenzufrieden & 0 & 2 & 1 & 2 & 2 & & 1 & 1 & 9 & 16 \\
\hline Fort & 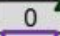 & 7 & 1 & 2 & 1 & $\sqrt{1}$ & & 0 & 6 & 11 \\
\hline $\begin{array}{l}\text { Klärung Eigentümer } \\
\text { Zielsetzung }\end{array}$ & 1 & 2 & 1 & 2 & 2 & 1 & 2 & & 11 & 20 \\
\hline Summe & & & & & & & & & 56 & 10 \\
\hline
\end{tabular}

Figure 1. Questionnaire used for the complete pairwise comparison and its conversion in percental preferences 
The pairwise comparison was transformed into a percentage by using a matrix that transforms the individual comparisons into a percental preference (Niklas 2002). This is executed in a way that in the case that the preferred item listed in the rows is more important than the column, a code 2 is used; code 1 is applied if equal importance $(=)$ is seen and 0 , when the item (row) is valuated as being less important. The sum of the codes related to the individual item (row) is used to derive the importance in percentages of the respective item by dividing by the total sum of codes. Figure $1 b$ shows the transformation of the questionnaire shown in Figure 1a. The average value for the individual group (WS 1, WS 2, Departments = Dept.) was calculated as a mean-value of the individual questionnaires.

To use these preferences for interpretation it has to be taken into account that the maximum of the percental preference is related to the number of items evaluated. The respective formula is: $100 /\left(\mathrm{N}_{\text {Items }} / 2\right)$. Thus the maximum is limited to the twofold rate of the average priority; the minimum preference value is zero (see also Figure 2).

\section{Surveys in the Top- and Middle-Level Management and Research Institute}

It was to be expected that in management the evaluation forms would be prepared by a member of the staff, but would have to then be authorized by the head of the department. The use of the questionnaires for a complete pairwise comparison is comparatively timeconsuming and does not immediately lead to the percental results, which could be approved easily by the heads of department. Consecutively, a different questionnaire was used in which the individual items had to be evaluated using a four point (forced) Likert scale $(++=$ important,$+=$ somewhat important,$-=$ somewhat unimportant,$--=$ unimportant $)$. In order to receive comparable results in terms of a percental evaluation, Likert values were used. The coding in the evaluation matrix was as follows: 2 was given if the Likert value of the row was higher than the value of the item in columns, 1 in case of equal preference and 0 when the row-Likert value indicated less importance (Figure 2).

\begin{tabular}{|l|c|c|c|c|c|c|c|c|}
\hline Items & $\begin{array}{c}\text { Likert } \\
\text { Value } \\
\text { (row) }\end{array}$ & Item 1 & Item 2 & Item 3 & Item 4 & Item 5 & Sum & $\begin{array}{c}\text { Percental } \\
\text { preference }\end{array}$ \\
\hline $\begin{array}{l}\text { Likert Value } \\
\text { column) }\end{array}$ & & + & -- & - & ++ & + & & \\
\hline Item 1 & + & & 2 & 2 & 0 & 1 & 5 & 25 \\
\hline Item 2 & -- & 0 & & 0 & 0 & 0 & 0 & 0 \\
\hline Item 3 & - & 0 & 2 & & 0 & 0 & 2 & 10 \\
\hline Item 4 & ++ & 2 & 2 & 2 & & 2 & 8 & 40 \\
\hline Item 5 & + & 1 & 2 & 2 & 0 & & 5 & 25 \\
\hline Sum & & & & & & & $\mathbf{2 0}$ & \\
\hline
\end{tabular}

Figure 2. Conversion of Likert scale evaluation into percental preferences

\section{Data}

We received 13 completed questionnaires in WS 1 and 22 in WS 2. These were questionnaires in which the complete version of the pairwise comparison was performed. Except for the dimension "Tasks", where we received 14 questionnaires, we had 13 from the various departments of SFA-BW Here the Likert scale version was used. 


\section{RESULTS}

\section{Objectives of FMP}

The results show - generally speaking - that the traditional objectives of FMP such as assurance of sustainability and the use of operative management are ranked best from almost all groups. The objectives related to potentially new objectives or external use of FMP (subsequently generally written in italics) show normally a clearly lower preference in percentages (Table 1).

Table 1. Objectives of FMP

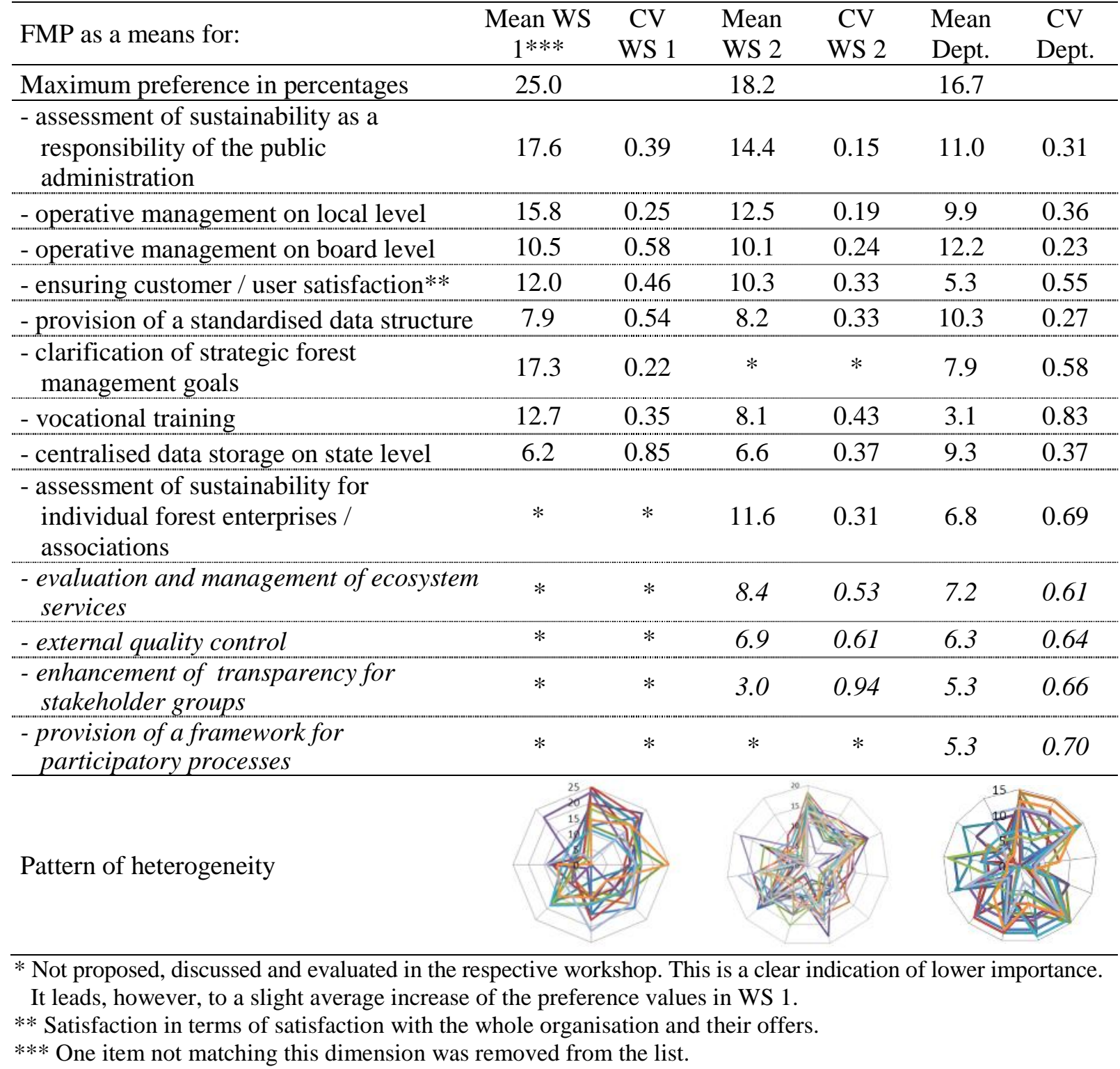

The coefficients of variation (CV) show mostly a lower or medium level with regard to the traditional objectives. However, even the CV provides only an overview of the variations of the preference patterns of the individual respondent. Based on the percental preference, netgraphs give an insight into the homo- or heterogeneity related to the individual dimension and respondent (See graphs at the bottom of tables 1-5). Despite the fact that individual differences are given, it can be stated that there is a lower heterogeneity at the county level in comparison to the evaluation of the departments. 


\section{Tasks of FMP}

It has to be mentioned again that the traditional tasks such as the control of the realisation of forest management plans are in the front. With regard to new requirements, the medium preference of the "integration of Natura 2000 management planning" task indicates that this aspect has gained importance in the last few years. There is strong evidence that the (already existing) use of external stakeholder groups (e.g. based on the Act on Information about Environment) is not seen as a preferred task of the FMP at the county level, whereas these functions are evaluated on average with more or less equal importance by the various departments. The heterogeneity on the county level (WS 1 and WS 2) was limited, however it was very significant at the department level. (Table 2).

Table 2. Tasks of FMP

\begin{tabular}{|c|c|c|c|c|c|c|}
\hline & $\begin{array}{l}\text { Mean } \\
\text { WS } 1\end{array}$ & $\begin{array}{c}\text { CV } \\
\text { WS } 1\end{array}$ & $\begin{array}{l}\text { Mean } \\
\text { WS } 2\end{array}$ & $\begin{array}{l}\mathrm{CV} \\
\mathrm{WS} 2 \\
\end{array}$ & $\begin{array}{l}\text { Mean } \\
\text { Dept. }\end{array}$ & $\begin{array}{l}\text { CV } \\
\text { Dept. }\end{array}$ \\
\hline Maximum percental preference & 10.5 & & 11.8 & & 9.5 & \\
\hline Control of FM-Plans realisation & 7.7 & 30.4 & 6.5 & 14.1 & 5.7 & 41.7 \\
\hline Planning of ranger districts & 8.1 & 30.1 & 6.4 & 26.7 & 5.1 & 45.9 \\
\hline Data base for GIS Applications & 7.3 & 24.3 & 5.8 & 30.0 & 6.4 & 32.6 \\
\hline Planning on stand level & 7.0 & 40.0 & 7.1 & 17.8 & 5.2 & 42.9 \\
\hline Inventory of basic forest data at stand level & 6.8 & 31.8 & 4.9 & 39.3 & 6.2 & 27.0 \\
\hline Proliferation of detailed data for individual stands & 6.4 & 37.8 & 6.1 & 23.9 & 5.1 & 52.6 \\
\hline Integration of Natura 2000 management planning & 5.4 & 40.7 & 4.6 & 25.2 & 6.2 & 32.8 \\
\hline Harmonisation of conflicting goals & 5.7 & 31.9 & 4.5 & 39.9 & 5.0 & 51.6 \\
\hline Database for reporting & 4.5 & 36.7 & 4.8 & 36.7 & 5.9 & 42.2 \\
\hline Database for financial planning & 6.2 & 34.5 & 5.1 & 31.3 & 3.7 & 68.6 \\
\hline Control of silvicultural standards & 6.1 & 24.7 & 4.5 & 30.6 & 4.1 & 56.9 \\
\hline Database for in depth analysis of special cases & 4.6 & 48.4 & 4.4 & 37.9 & 5.3 & 48.6 \\
\hline Silvicultural training & 6.3 & 32.4 & 4.4 & 28.4 & 2.3 & 97.1 \\
\hline Vocational training & 5.0 & 44.0 & 3.5 & 38.1 & 3.1 & 70.4 \\
\hline $\begin{array}{l}\text { Provision of information for forest } \\
\text { certification (FSC/PEFC) }\end{array}$ & 3.6 & 69.2 & 2.0 & 66.6 & 5.3 & 47.7 \\
\hline $\begin{array}{l}\text { Integrated (environmental. managerial planning) } \\
\text { at stand level }\end{array}$ & $*$ & $*$ & 5.2 & 36.8 & 4.8 & 38.2 \\
\hline Process development & 3.6 & 35.8 & 3.0 & 54.3 & 3.1 & 78.6 \\
\hline Database for Sustainability Balanced Scorecard & 3.3 & 74.5 & $*$ & $*$ & 5.1 & 47.4 \\
\hline $\begin{array}{l}\text { Database for proliferation of information based } \\
\text { on the act on information about environment }\end{array}$ & 2. & 129.0 & $*$ & $*$ & 5.0 & 43.5 \\
\hline Forest monitoring & $*$ & $*$ & $*$ & $*$ & 4.3 & 59.1 \\
\hline $\begin{array}{l}\text { Information on areas suitable for compensation for } \\
\text { environmental relevant impacts }\end{array}$ & $*$ & $*$ & $*$ & $*$ & 2.9 & 98.2 \\
\hline Pattern of heterogeneity & & & & & & \\
\hline
\end{tabular}

* Not evaluated. Due to the lower share of non-evaluated items there is no relevant impact on the average preference pattern of the other items. 


\section{Tools and Products of FMP}

The high preference for traditional outputs of FMP is even stronger at the county level when the question for tools and products is raised. The highest percental ranking receives the total felling budget, stand register, and planning information on stand level. The evaluation of the departments' questionnaire shows a more evenly structured preference pattern. As in the other dimensions examined, the role of new products meets on average wide scepticism amongst the representatives of the county level, but the normally high CV indicates that a smaller part of the group has a different view on these externally used products. With regard to the preference pattern of the individual evaluator, it can be shown that we have here a tremendous heterogeneity in all groups. The requirements seem to vary significantly among different regions or under a different thematic scope of the departments (Table 3).

Table 3 (part 1). Tools and Products of FMP

\begin{tabular}{|c|c|c|c|c|c|c|}
\hline & $\begin{array}{l}\text { Mean } \\
\text { WS } 1\end{array}$ & $\begin{array}{c}\text { CV } \\
\text { WS } 1 \\
\end{array}$ & $\begin{array}{l}\text { Mean } \\
\text { WS } 2 \\
\end{array}$ & $\begin{array}{c}\mathrm{CV} \\
\mathrm{WS} 2 \\
\end{array}$ & $\begin{array}{l}\text { Mean } \\
\text { Dept. }\end{array}$ & $\begin{array}{l}\text { CV } \\
\text { Dept. }\end{array}$ \\
\hline Maximum percental preference & 6.9 & & 6.9 & & 6.3 & \\
\hline Total felling budget & 5.5 & 0.19 & 4.5 & 0.24 & 4.1 & 0.34 \\
\hline Resuming of silvicultural measures & 4.9 & 0.23 & 4.5 & 0.20 & 4.1 & 0.34 \\
\hline Forest GIS & 4.7 & 0.31 & 4.5 & 0.22 & 4.2 & 0.30 \\
\hline Stand register & 5.5 & 0.17 & 3.5 & 0.43 & 4.0 & 0.36 \\
\hline $\begin{array}{l}\text { Management plans for individual } \\
\text { stands }\end{array}$ & 5.4 & 0.26 & 4.0 & 0.36 & 3.6 & 0.47 \\
\hline Digital maps & 5.3 & 0.22 & 3.4 & 0.36 & 4.3 & 0.26 \\
\hline Digital stand information & 3.4 & 0.33 & 4.1 & 0.22 & 4.3 & 0.21 \\
\hline $\begin{array}{l}\text { Resuming of activities in areas } \\
\text { under different kinds of treatment } \\
\text { (planting. pruning. harvesting ...) }\end{array}$ & 5.2 & 0.22 & 3.2 & 0.42 & 2.7 & 0.49 \\
\hline Traditional (hardcopy) maps & 5.3 & 0.21 & 3.0 & 0.47 & 2.7 & 0.54 \\
\hline $\begin{array}{l}\text { Permanent comparability between } \\
\text { plan and completion on stand level }\end{array}$ & 4.1 & 0.43 & 4.3 & 0.17 & 2.6 & 0.51 \\
\hline Plan for individual ranger districts & 4.7 & 0.31 & 3.6 & 0.39 & 2.3 & 0.70 \\
\hline Standard reports & 3.3 & 0.46 & 4.4 & 0.18 & 2.9 & 0.54 \\
\hline Digital cadastral information & 2.9 & 0.47 & 3.5 & 0.34 & 4.0 & 0.26 \\
\hline $\begin{array}{l}\text { Information about structure and } \\
\text { spatial affiliation of land parcels }\end{array}$ & 3.4 & 0.49 & 3.8 & 0.24 & 3.2 & 0.40 \\
\hline Maps about specialised questions & 3.6 & 0.37 & 3.8 & 0.23 & 3.0 & 0.44 \\
\hline $\begin{array}{l}\text { Management summary for } \\
\text { decision-makers }\end{array}$ & 4.1 & 0.38 & 3.4 & 0.30 & 2.7 & 0.58 \\
\hline Special analysis & 2.6 & 0.64 & 3.7 & 0.22 & 3.4 & 0.32 \\
\hline Mapping of forest habitat types & 2.5 & 0.70 & 3.5 & 0.42 & 3.4 & 0.36 \\
\hline $\begin{array}{l}\text { Strategic management planning on } \\
\text { enterprise level }\end{array}$ & 4.2 & 0.31 & 2.1 & 0.53 & 2.9 & 0.56 \\
\hline Provision of time series & 2.4 & 0.45 & 2.7 & 0.47 & 3.3 & 0.42 \\
\hline $\begin{array}{l}\text { Felling plan structured by timber- } \\
\text { assortments }\end{array}$ & 3.8 & 0.43 & 1.5 & 0.62 & 2.9 & 0.66 \\
\hline Operations analysis & 2.9 & 0.39 & 2.6 & 0.44 & 2.6 & 0.87 \\
\hline
\end{tabular}


Table 3 (part 2). Tools and Products of FMP

\begin{tabular}{|c|c|c|c|c|c|c|}
\hline & $\begin{array}{l}\text { Mean } \\
\text { WS } 1\end{array}$ & $\begin{array}{l}\text { CV } \\
\text { WS } 1\end{array}$ & $\begin{array}{l}\text { Mean } \\
\text { WS } 2\end{array}$ & $\begin{array}{l}\text { CV } \\
\text { WS } 2 \\
\end{array}$ & $\begin{array}{l}\text { Mean } \\
\text { Dept. }\end{array}$ & $\begin{array}{l}\text { CV } \\
\text { Dept. }\end{array}$ \\
\hline $\begin{array}{l}\text { Management contract between } \\
\text { owner and manager }\end{array}$ & 0.0 & 0.00 & 4.7 & 0.24 & 3.2 & 0.54 \\
\hline $\begin{array}{l}\text { Experts' opinion for the } \\
\text { management of the elapsed period }\end{array}$ & 2.3 & 0.43 & 2.8 & 0.33 & 2.2 & 0.64 \\
\hline $\begin{array}{l}\text { Specialised analysis for different } \\
\text { zones }\end{array}$ & 0.0 & 0.00 & 3.4 & 0.32 & 3.5 & 0.55 \\
\hline Forest statistical report & 1.8 & 0.44 & 2.0 & 0.82 & 2.8 & 0.47 \\
\hline $\begin{array}{l}\text { List of individual stand matching } \\
\text { special criteria }\end{array}$ & 0.0 & 0.00 & 3.5 & 0.30 & 2.3 & 0.65 \\
\hline $\begin{array}{l}\text { Digital information for external } \\
\text { stakeholders and partners }\end{array}$ & 1.7 & 0.89 & 1.5 & 0.94 & 2.3 & 0.78 \\
\hline $\begin{array}{l}\text { Digital GIS information for } \\
\text { external stakeholders and partners }\end{array}$ & 1.8 & 1.02 & 1.4 & 0.96 & 2.3 & 0.78 \\
\hline Map of Natura 2000 areas & $*$ & $*$ & $*$ & $*$ & 3.5 & 0.22 \\
\hline $\begin{array}{l}\text { Description of present state of } \\
\text { stand level }\end{array}$ & $*$ & $*$ & $*$ & $*$ & 3.0 & 0.56 \\
\hline $\begin{array}{l}\text { Dynamic maps which depict } \\
\text { changes over time during a } \\
\text { planning period. }\end{array}$ & $*$ & $*$ & $*$ & $*$ & 1.8 & 0.70 \\
\hline Pattern of heterogeneity & & & & & & \\
\hline
\end{tabular}

* Not assessed at the county level.

\section{Users of FMP}

The analysis of the preferred user groups shows a clear result. There is a wide consensus that the state FMP system should be suited for a wide range of forest users. Except for the private forest owners, which are not favoured by the departments, all ownership types and managers of different levels show a distinct and greater importance. The comparatively low CV related to the forests users indicate a low heterogeneity, which is additionally supported by the patterns of heterogeneity (Table 4).

\section{Process Steps}

It can be stated that there are two process steps which are ranked best in all groups. These are the joint inspection of the individual stands and a discussion about the core objectives to be executed during the next ten-year planning period. The potential role of the FMP as a platform for participatory processes was only assessed at the department level and was not seen as playing an important part of the FMP process. However, as it is normal for new aspects, it showed a high CV, indicating different opinions at the department level. 
Table 4. User groups of FMP

\begin{tabular}{|c|c|c|c|c|c|c|}
\hline & $\begin{array}{l}\text { Mean } \\
\text { WS } 1\end{array}$ & $\begin{array}{l}\text { CV } \\
\text { WS } 1\end{array}$ & $\begin{array}{l}\text { Mean } \\
\text { WS } 2\end{array}$ & $\begin{array}{c}\text { CV } \\
\text { WS } 2\end{array}$ & $\begin{array}{l}\text { Mean } \\
\text { Dept. }\end{array}$ & $\begin{array}{l}\text { CV } \\
\text { Dept }\end{array}$ \\
\hline Maximum percental preference & 20.0 & & 16.7 & & 15.3 & \\
\hline $\begin{array}{l}\text { Owners and managers of state } \\
\text { forest land }\end{array}$ & 14.2 & 0.18 & 11.5 & 0.13 & 13.2 & 0.12 \\
\hline $\begin{array}{l}\text { Owners and managers of communal } \\
\text { forest land }\end{array}$ & 16.8 & 0.19 & 13.8 & 0.09 & 11.5 & 0.21 \\
\hline $\begin{array}{l}\text { Owners and managers of private } \\
\text { forest land }\end{array}$ & 14.3 & 0.25 & 12.4 & 0.16 & 5.5 & 0.65 \\
\hline $\begin{array}{l}\text { Managers on board level } \\
\text { (state forest) }\end{array}$ & 12.2 & 0.13 & 10.7 & 0.21 & 12.8 & 0.11 \\
\hline $\begin{array}{l}\text { Managers on local level } \\
\text { (including forest rangers) }\end{array}$ & 12.4 & 0.19 & 12.8 & 0.18 & 11.7 & 0.32 \\
\hline Other administrations & 7.8 & 0.38 & 7.6 & 0.37 & 9.0 & 0.37 \\
\hline Hunters & 2.5 & 0.60 & 2.1 & 0.51 & 3.2 & 1.15 \\
\hline$N G O s$ & 5.2 & 0.79 & 3.2 & 0.80 & 5.8 & 0.56 \\
\hline Citizens & 8.0 & 0.65 & 7.1 & 0.51 & 5.6 & 0.48 \\
\hline Timber consumers & 6.6 & 0.59 & 5.9 & 0.44 & 4.3 & 0.68 \\
\hline Forest associations & $*$ & $*$ & 8.5 & 0.43 & 5.2 & 0.45 \\
\hline Certifiers & $*$ & $*$ & 4.4 & 0.46 & 9.1 & 0.32 \\
\hline Adjacent forest owners & $*$ & $*$ & $*$ & $*$ & 3.3 & 0.66 \\
\hline Pattern of heterogeneity & & & & & & \\
\hline
\end{tabular}

Table 5: $\quad$ Importance of process-steps in the FMP-process

\begin{tabular}{|c|c|c|c|c|c|c|}
\hline & $\begin{array}{l}\text { Mean } \\
\text { WS } 1\end{array}$ & $\begin{array}{c}\text { CV } \\
\text { WS } 1 \\
\end{array}$ & $\begin{array}{l}\text { Mean } \\
\text { WS } 2 \\
\end{array}$ & $\begin{array}{c}\mathrm{CV} \\
\mathrm{WS} 2 \\
\end{array}$ & $\begin{array}{l}\text { Mean } \\
\text { Dept. }\end{array}$ & $\begin{array}{l}\text { CV } \\
\text { Dept. }\end{array}$ \\
\hline Maximum percental preference & 40.0 & & 40.0 & & 33.3 & \\
\hline $\begin{array}{l}\text { Joint inspections (district ranger and } \\
\text { a member of FMP organisation) }\end{array}$ & 23.1 & 0.38 & 24.4 & 0.38 & 19.5 & 0.43 \\
\hline Discussion about a set of objectives & 20.0 & 0.28 & 20.3 & 0.43 & 23.3 & 0.22 \\
\hline Debriefing & 17.7 & 0.46 & 16.3 & 0.44 & 16.9 & 0.50 \\
\hline Negotiations during FMP process & 13.1 & 0.48 & 14.9 & 0.54 & 19.2 & 0.45 \\
\hline $\begin{array}{l}\text { Participative processes with } \\
\text { external stakeholders }\end{array}$ & $*$ & $*$ & $*$ & $*$ & 11.9 & 0.89 \\
\hline Mid-term meeting & 4.4 & 1.69 & 9.4 & 0.82 & 10.0 & 0.97 \\
\hline Pattern of heterogeneity & & & & & & \\
\hline
\end{tabular}




\section{DISCUSSION}

\section{Objectives}

The results give a clear indication that traditional goals of FMP are still absolutely predominant. FMP as a means to control the forest enterprise at the local level or to ensure the legal obligation to manage forests in a sustainable manner are emphasised homogenously at the county level and at the department level. The results from the two workshops at the county level show a wide overlap, hence we can conclude that the underlying hypothesis that no relevant regional differences exist was proven successfully. However, it is evident that some differences remain as well. The clarification of the set of goals of the individual owner is much more important at the county level and the same applies for the satisfaction of most communal users of FMP. Still, this applies for the internal use of FMP as well. All 'new' objectives are on average of lower priority; at the local level the results indicate that there is tremendous scepticism towards integration of such kind of objectives when designing a new FMP processes. The reasons behind this attitude were not assessed during the process; however, the novelty of these requirements may play a substantial role. It has to be pointed out that a higher CV indicates that there is a smaller share of county representatives, who displayed a different opinion. The awareness seems to differ notably at the local level, which corresponds with the wide variety of framework conditions reaching from condensed urban areas to rural landscapes. One should expect that these 'new objectives' are of much higher relevance on the upper management levels. Despite the fact that the average evaluation shows a higher ranking at the department level than in the counties, it has to be stated that there is no common evaluation of these new potential objectives at the department level either.

\section{Tasks of FMP}

Firstly, it has to be mentioned that the plurality of opinions is mostly higher when individual tasks of FMP are analysed. We found a lower CV $(<0.40)$ for roughly only $50 \%$ of the tasks, which indicates that there is a broader consensus about the importance of the individual task; only five tasks could be identified, which are seen as being of greater relevance in all groups. With regard to the operative tasks of FMP, analysis shows that the requirements of the local level are completely different from those of the departments. County members voted definitely for tasks, which are in context to silvicultural activities on the stand and district level, whereas the departments showed a higher affinity to external functions of FMP such as certification, the controlling of strategic goals in the Sustainability Balanced Scorecard e.g. Here we identify a notable difference between the requirements of the different management levels and thus likely a point of future disputes in the case that the revised version of FPM is not able to cover both the preferred tasks of the local level and the wider range of tasks evaluated as being important by the departments.

\section{Process Steps}

Above all, it has to be realised that the heterogeneity of opinions about the importance of individual process steps is on a medium level, but there are no differences on average between the two workshops at the county level. With regard to the FMP processes, it turns out that there are only two process steps which are seen as prevalent: first, a joint inspection of the individual stands by the local ranger and the person who is responsible of the FMP; second, a discussion about the set of objectives, which received homogenously high preference in percentages. According to the findings discussed below, the possibility of the integration of external stakeholders meets wide scepticism. Again, the exclusion of externals becomes visible, and it can be shown that it reflects not only the opinion at the county level. At the 
department level the heterogeneity, indicated by a high $\mathrm{CV}$ of 0.89 , indicates various points of view on this account too. Unless it is known that there is a high demand from external stakeholder groups (environmental NGOs play the most substantial role), no common understanding of whether a framework for an external participation should be integrated in the FMP process was developed thus far, not even at the medium and upper management level.

\section{Tools and Products}

The results of the analysis of the tools and/or products provided by the FMP mirror those of the tasks and objectives. Again, traditional products/tools are characterised by a homogenously higher or medium preference. It can be shown that the preference structure of the department level differs substantially from that of the counties, where products which can be used directly from the field foresters are ranked - foreseeably- higher. Half of the products - mostly traditional ones - are evaluated to have a limited heterogeneity, and such is the case especially at the county level. The notably higher heterogeneity observed for products, which are suited to be used by or even mostly dedicated to externals, highlights the greater differences between the counties and departments in terms of relevance of participation and issues such as ecosystem services.

\section{Users}

The importance of different users of FMP is very homogenous when we consider the traditional users and stakeholders, which are the various communal enterprises (here especially at county level) and the representatives and managers of state forest land at the local and board level. New, mostly external users are viewed very sceptically at the county level. Other administrations and certifiers receive a homogenous, but only medium high, preference at the department level. Citizens and forest associations are, in general, of low importance. The higher CV indicates again that it needs the direct perception of a demand from external stakeholder groups, which can be observed only locally or in some departments that are confronted with these external requests. Consequently, the results reveal that it is again the traditional mind-set that dominates the approach regarding the users of FMP. It can be questioned whether this is forward-looking in a time, where political decision-makers have decided to publish detailed information and data from the FMP to the public.

\section{Summarising comments}

The patterns of the preferences confirm the expectations. For most members of forest administration, FMP has to primarily fulfil the traditional functions of their silvicultural activities. However, the heterogeneity even at the county level shows that the demand for new aspects differs widely. This corresponds with the tremendous variability of the framework conditions under which forest management takes place in Baden-Württemberg. It varies from forests situated close to urban congestions, which are to some extent heavily influenced by a high share of academically educated people, to rural regions where primary productions still play a significant role. It has to be stated that up to now no widespread intrinsic motivation to adopt these new aspects exists; it is more of an externally forced local shift in areas where a higher demand for societal participation has already developed. Furthermore, this plurality of opinions is not limited to the county level. At the middle and top management levels the heterogeneity is similar, but evidently and expectably the perception of the increasing demand of stakeholders for information and products from FMP is higher.

From a methodological point of view it can be confirmed that the pairwise comparison methods, which have met scepticism before the beginning of the process, have proved successful. The results show a clear consistency over the individual dimensions. Forest 
management experts and decision-makers from the state forest enterprise unanimously stated that the results are to the point. The ability to arrange the individual items into a matrix with the axes corresponding to the importance and consentaneity can be used as guidance for strategic decisions about the core objectives and structural components of a future FMPprocess. Despite the fact that the results proved the existing hypotheses in almost every case, additional information about the degree of consensus and presentability in the future process were identified as a valuable benefit of the process.

\section{CONCLUSIONS, RECOMMENDATIONS AND OUTLOOK}

The questionnaire and pairwise comparison methods can be seen as helpful tools when a clear and visible prioritisation is needed. Particularly the opportunity to deliver results, which are due to its participants' absolute anonymity - more or less uninfluenced by hierarchical structures, is suited to derive an insight into the individual opinions in a group and reduce the chance to show tactical response behaviour.

The number of assessment criteria related to a topic or a dimension should be limited to 15-20 items. Questionnaires, which require up to 450 entries, are very time-consuming and are only applicable in groups with a strong willingness for cooperation. Means for reducing the number of items can be seen in a pre-selection using less sophisticated methods or the use of a higher number of dimensions or topics. When using (hardcopy) questionnaires, the result cannot be displayed in a workshop setting. This non-visibility leads to some degree of disappointment amongst the participants. The use of digital surveying methods is, when applicable, better suited when the results should be presented immediately. Furthermore, it reduces the workload of data entry tremendously. Excel applications can also be designed easily.

The percental preferences can and will be used as a framework for the application of a decision support tool. At the present stage this will be a utility analysis in which different structurally diverse FMP alternatives are compared using the percental preferences as utility values. The data could be used in other decision support systems (DSS) such as the Analytical Hierarchical Process. Regardless of which DSS is used, only the structured data derived from the evaluation process described above will allow for an undertaking of further supportive activities such as sensitivity-analysis or a comparison of different variations of the upcoming FMP in the ongoing development process in a reliable und trustworthy manner.

Acknowledgements: We thank the uncomplaining participants from the county level workshops who actively completed questionnaires for about an hour, and our students who helped us with compiling and entering all the data into a complex system.

\section{REFERENCES}

BECK, S.M. (2001): Partizipative Planungsinstrumente für eine nachhaltige und multifunktionale Waldbewirtschaftung. Schriftenreihe Freiburger Forstliche Forschung 49/2011. FVA BadenWürttemberg. $187 \mathrm{p}$.

EUROPEAN COMMISSION (1992): Council Directive 92/43/EEC on the Conservation of natural habitats and of wild fauna and flora.

EUROPEAN COMMISSION (2013): Guidance on Natura 2000 and Forests. (Draft Version, work in Progress). 
FEINDT, P.H.; NEWIG, J. (2005): Partizipation, Öffentlichkeitsbeteiligung, Nachhaltigkeit. Perspektiven der politischen Ökonomie. Metropolis Verlag für Ökonomie, Gesellschaft und Politik GmbH. 327 p.

GRI (Global Reporting Initiative) (2013): Sustainability Reporting Guidelines. Global Reporting Initiative, Amsterdam. 92 p.

Online: https://www.globalreporting.org/reporting/g4/Pages/default.aspx.

HARTEBRODT, C. (2009): Benefits of information and internal and external participation during implementation of a sustainability balanced scorecard in a public enterprise. Proceedings of the Conference "Theory and practice in performance measurement". Dunedin, New Zealand, 14.-17.04.2009. $17 \mathrm{p}$.

HEINRICHS, H. (2007):Partizipation und Nachhaltigkeit. In Michelsen, G. - Godemann, J.; (eds.): Handbuch Nachhaltigkeitskommunikation: Grundlagen und Praxis. 2nd edition, oecom verlag, München. 715-726.

JoInt FAO/CE/ILO COMmitTEE On Forest TEChNOLOGy, MANAGEMENT AND TRAINING (2000): Public Participation in Forestry in Europe and North America. International Labour Office (ILO) Geneva, Sectoral Activities Department. 130 p.

LWaldG (2012): Waldgesetz für Baden-Württemberg. Kohlhammer-Verlag, 14. Lieferung Nov. 2012. $312 \mathrm{p}$.

NiKLAS, C. (2002): Mehr Entscheidungssicherheit mit der Nutzwertanalyse. Projektmagazin 7/2014, Berleb Media GmbH, Taufkirchen. Online:

https://www.projektmagazin.de/artikel/mehr-entscheidungssicherheit-mit-der-nutzwertanalyse_ 1089305.

SAATY, T.L. (2008) Relative Measurement and Its Generalization in Decision Making - Why Pairwise Comparisons are Central in Mathematics for the Measurement of Intangible Factors - The Analytic Hierarchy/Network Process. Rev. R. Acad. Cien. Serie A. Mat. VOL. 102 (2), 2008, pp. 251-318.

SHEPPARD, S.R.J. (2005): Participatory Decision Support for Sustainable Management: A Framework for Planning with Local Communities at the Landscape Level in Canada. In: Canadian Journal of Forest Research 35: 1515-1526. 